\title{
The Biology, Utilization and Phytochemical Composition of the fruits and leaves of Gongronema latifolium Benth
}

\author{
Osuagwu AN*, Ekpo IA, Okpako EC, Otu P and Ottoho E
}

Department of Genetics and Biotechnology, University of Calabar, Nigeria

\begin{abstract}
Basic information on plant species is important for the improvement of the species. This study was carried out to investigate and understand the biology, utilization and phytochemical composition of Gongronema latifolium which is a spice plant growing in the humid forest vegetation of South- Eastern Nigeria. Results showed that the species had culinary and medicinal properties. G. latifolium has simple and opposite leaves, dehiscent seed pod (follicle), that opens along a single seam. The seeds are flat with white hairy pappus, The flowers are bisexual, regular with pale yellow coloured petals and superior ovary. Phytochemical analysis of the tender fruits and mature leaves of Gongronema latifolium revealed the presence of alkaloids, tannins, saponins, flavonoids, phenols, phytic acid and hydrocyanic acid. The phytochemicals were higher in the fruitscompared to the leaves $(P<0.001)$ except the flavonoids which were higher in the leaves than in the fruits $(P<0.001)$. The presence of these phytochemicals account for the nutriceutical /medicinal properties of Gongronema latifolium.
\end{abstract}

Keywords: Gongronema latifolium; biology; utilization; phytochemical analysis; plant morphology

\section{Introduction}

The tropical rainforest is the most biologically diverse ecosystem on the earth and it is the predominant natural forest in Nigeria. It is favorable for the production of a wide range of useful plants and spices including Gongronema latifolium [1,2]. Plants and plant-products are good sources of medications and provide raw materials for modern pharmaceuticals used for various ailments [3]. A great number of the world's population particularly Nigerians, rely on traditional medicines for their primary health care needs.

The medicinal value of plants lies in some chemical substances that produce a definite physiologic action on the human body. The most active of these bioactive compounds (phytochemicals) of plants are alkaloids, flavonoids, tannins and phenolic compounds [4]. Phytochemicals are chemical compounds that occur naturally in plants and which may affect health and are not yet established as essential nutrients [5]. Phytochemicals give plants their color, flavour, smell and texture. Kushi et al., Setchell and Cassidy, and Wang et al. [68] reported that phytochemicals work to affect antioxidant activity, hormonal action, stimulation of enzymes, interference with DNA replication, and antibacterial effect among others. As time goes by, our typical diets seem to increasingly contain more fatty processed foods and less natural plant based foods. The result of this disturbing trend can be seen in the alarming statistics on cancer, heart diseases, stroke and many other degenerative diseases. Aside from dietary problems, there is a problem of inadequate intake of plant based foods and all the benefits they bring with them. On the other hand, with increase in population and socio-economic changes leading to high rates of urbanization, need for more houses as well as increased commercialization of agricultural productions, natural forests that are rich sources of useful plants are being destroyed in a large scale [9]. Gongronema latifolium is of huge importance in food and medicine, but there is a gross lack of knowledge in the biology of this plant species and its utilization viz a viz its phytochemical composition. This consideration has made it important to investigate and understand the biology, phytochemical composition and utilization of the species. This information will be invaluable for any subsequent improvement and conservation of the plant.

\section{Materials and Methods}

The Gongronema latifolium samples used in this study were collected from four States in the South- Eastern zone of Nigeria and planted in the experimental fields of the Department of Genetics and Biotechnology, University of Calabar. The four States are Abia State, Akwa Ibom State, Cross River State and Imo State (Table 1). Stem cuttings of the species were raised in the nursery for one month before transplanting in the field. Cultural practices such as weeding and staking were carried out. The plants were monitored for three years (Feb, 2009-Feb, 2012) to determine the time of maturity (flowering and fruiting) and the consistency in the biological processes such as germination of its seeds. Taxonomic identification and classification of different parts of the plant (leaves, flowers, fruits, and seeds) were carried out in the Department of Botany, University of Calabar and through literature review.

Studies on the utilization of Gongronema latifolium were based on oral interviews with various respondents at each State where collections were made. A total of 80 respondents ( 20 from each State), were interviewed. This number included farmers, traditional doctors,

\begin{tabular}{|l|l|l|l|l|l|}
\hline State & LGA & Village & $\begin{array}{l}\text { Latitude } \\
{ }^{\mathbf{} N}\end{array}$ & $\begin{array}{l}\text { Longitude } \\
{ }^{\circ} \text { E }\end{array}$ & $\begin{array}{l}\text { Altitude } \\
(\mathbf{m})\end{array}$ \\
\hline Cross River & Akamkpa & Iko-Ekperem & 05.6068 & 08.2170 & 10.32 \\
\hline Imo & Ngor Okpala & Umuogba Ntu & 04.9975 & 08.3330 & 45.3 \\
\hline Abia & Ikwuano & Umudike-Uku & 04.8604 & 7.7843 & 121 \\
\hline Akwa Ibom & Etinan & Ikot Udobia & 04.8863 & 7.8299 & 67 \\
\hline
\end{tabular}

Table 1: Collection sites of Gongronema latifolium.

*Corresponding author: Osuagwu AN, Department of Genetics and Biotechnology University of Calabar, P.M.B 1115,Calabar, Nigeria, Tel: 2348063603103; E-mail: anniosuagwu@gmail.com

Received August 09, 2013; Accepted November 12, 2013; Published November 20, 2013

Citation: Osuagwu AN, Ekpo IA, Okpako EC, Otu P, Ottoho E (2013) The Biology, Utilization and Phytochemical Composition of the fruits and leaves of Gongronema latifolium Benth. Agrotechnol 2: 115. doi:10.4172/2168-9881.1000115

Copyright: @ 2013 Osuagwu AN, et al. This is an open-access article distributed under the terms of the Creative Commons Attribution License, which permits unrestricted use, distribution, and reproduction in any medium, provided the original author and source are credited. 
housewives, traders and other users of G. latifolium. Phytochemical screening of the fruits and leaves of G. latifolium was carried out in the laboratory of the Department of Pure and Applied Chemistry, University of Calabar, Calabar. The mature leaves and tender green fruits samples were oven dried at $50^{\circ} \mathrm{C}$ for three days, ground to fine powder and stored in dry containers for further analysis. Quantitative phytochemical analyses were carried out to determine alkaloids, tannins, saponins, flavonoids, phenols, phytic acid, oxalate and hydrocyanic acid, Using standard methods described by Sofowora [10], Edeoga et al. [11], Trease et al. [12], Andrews [13], with three replications and the results were recorded in percentages.

\section{Determination of Phytochemicals}

Alkaloids: $2 \mathrm{~g}$ of sample were weighed and added to $1 \mathrm{ml}$ of concentrated acetic acid and ethanol (1:2), covered and kept to stand for $4 \mathrm{hrs}$ then filtered and concentrated in a water bath to one-quarter $(1 / 4)$ of the original volume. Concentrated ammonium hydroxide was added drop-wise to the extract until the precipitate formation was completed. It was then allowed to settle and washed and filtered with dilute ammonium hydroxide solution. The residue was dried in an oven and taken as crude alkaloid. It was weighed and recorded.

Tannins: Tannin was extracted from $0.5 \mathrm{~g}$ of the sample with methanol then purified with Whatman filter paper. Colour was developed using Vanillin hydrochloric acid reagent and the concentration was quantitatively measured using a spectrophotometer at $500 \mathrm{~nm}$.

Saponins: $2 \mathrm{~g}$ of sample were extracted with ethanol which was subsequently removed using a rotary evaporator. The solution was washed with diethyl ether until colorless. The $\mathrm{pH}$ was adjusted to 5.0 with sodium chloride. Finally, it was extracted with n-butanol and washed with sodium chloride and evaporated to dryness to give saponins which were weighed and recorded.

Flavonoids: $2 \mathrm{~g}$ of samples were extracted with $100 \mathrm{ml}$ of $80 \%$ aqueous methanol at room temperature until the supernatant became colorless. The solution was filtered through Whatman filter paper. The filtrate was transferred into a beaker and evaporated to dryness over a hot plate to give flavonoids which was weighed and recorded.

Phenols: $2 \mathrm{~g}$ of samples were weighed and $50 \mathrm{ml}$ of ether was added. The slurry was agitated for 15 minutes. $5 \mathrm{ml}$ amyl alcohol was added and allowed for 30 minutes for the development of the color. The concentration of the solution was determined using uv-vis spectrophotometer at $505 \mathrm{~nm}$.

Phytic acid: $2 \mathrm{~g}$ of sample were weighed and added to $25 \mathrm{ml}$ of 0.5 $\mathrm{N} \mathrm{NaCl}$ then was shaken for 30 minutes. $2 \mathrm{ml}$ of ferric chloride was added to the extract. The precipitate (ferric phytate) was converted to sodium phytate by adding $3 \mathrm{ml}$ of sodium hydroxide. The precipitate was digested with acid mixture of equal portions of concentrated tetraoxosulphate (VI) acid and perchloric acid in a digestion set. The liberated phosphorus was quantified calorimetrically at $620 \mathrm{~nm}$ after color development with molybdate reagent.

Oxalate: $2 \mathrm{~g}$ of sample were weighed and extracted with dilute hydrochloric acid. The oxalate in the extract was precipitated with calcium chloride as salts. The precipitated extract was washed with 50 $\mathrm{ml}$ of $25 \% \mathrm{H}_{2} \mathrm{SO}_{4}$ and dissolved in hot water then was titrated with $0.05 \mathrm{~N} \mathrm{KMnO}_{4}$.

$1 \mathrm{ml}$ of $0.05 \mathrm{~N} \mathrm{KMNO}_{4}=2.2 \mathrm{mg}$ oxalate.
Hydrocyanic acid: $2 \mathrm{~g}$ of sample was weighed and soaked in $50 \mathrm{ml}$ of distilled water for about $4 \mathrm{hrs}$ and then steam distilled into $50 \mathrm{~cm}^{3}$ of $2.5 \% \mathrm{NaOH}$ in a beaker. $8 \mathrm{ml}$ of $6 \mathrm{~N} \mathrm{NH}_{4} \mathrm{OH}$ and $2 \mathrm{ml}$ of $5 \% \mathrm{KI}$ was added to the $25 \mathrm{~cm}^{3}$ portion of the distillate and $0.05 \mathrm{~N}$ silver nitrate was titrated against it to a faint and permanent turbidity.

$1 \mathrm{ml}$ of $0.02 \mathrm{~N} \mathrm{AgNO}_{3}=1.08 \mathrm{mg} \mathrm{HCN}$

\section{Data analysis}

Data collected were analyzed using the $t$-test and descriptively using the means and standard error.

\section{Results and Discussion}

\section{Biology of Gongronema latifolium}

Gongronema latifolium is a flowering plant of the order Gentiales and the family Apocynaceae, Subfamily Asclepiadaceae, and genus Calotropis. It is a tropical climbing plant (lianas woody) distributed mainly in the tropical and sub tropical regions of Africa, Asia and Oceania [14-16]. It is propagated by stem cuttings as well as by seeds. The species takes up to one year to fully mature and flower.

The study showed that the leaves of Gongronema latifolium are simple, opposite, decussate and whorled, peltate with entire margin and long petiole (about $5.2 \mathrm{~cm}$ long) (Plates A and B). The leaves area measured approximately $50.2 \mathrm{~cm}^{2} \pm 0.35 \mathrm{~cm}^{2}$. The inter node length varied according to the habitat, and reached up to $30 \mathrm{~cm}$ in length in shady environments such as forest floors or less than $5 \mathrm{~cm}$ in exposed regions. The roots are adventitious arising wherever the soft woody stem makes contact with soil.

Flowers of $G$. latifolium are bisexual and actinomorphic. Inflorescences are extra-axillary cymes. The calyx has five basal glands; the corolla is urceolate with five lobes. There are five lobes of scalelike corona inserted at the base of gynostegium. The stamens are five while the filaments are connected into a tube. Anthers are erect with membranous apical appendages. There are two pollinia per pollinarium, and the styles are short. The stigma heads are vertically conical in shape. Ovary is superior. The flowers are pale yellow in colour (Plate C).

The fruit of Gongronema latifolium is a dehiscent seed pod called a follicle which is oblong- lanceolate. The colour of the fruits varied from green in small fruits to dark brown to black at maturity. During maturity stage, the fruit splits open length wise, along the seam releasing flat seeds, the seeds are attached to a white silky tuft (pappus) which aids dispersal.The seeds are strongly compressed, coma shaped and measure about $0.5 \mathrm{~cm}$ in length (Plates D, E and F (Figure 1)).

G. latifolium established from stem cuttings grow and mature in twelve months. Flowering was initiated in late January and went on through March. Day temperatures at this period in the region ranged between $32^{\circ} \mathrm{C}-37.5^{\circ} \mathrm{C}$. The flowers are insect pollinated. Fruit development in the species is a slow process lasting from April through November, when the fruits begin to mature and change color from green to black and eventually dehisce in the later part of dry season (December to February). New flowers often meet old fruits on the plant. Mature seeds of G. latifolium planted within two weeks after harvest germinated in seven to fourteen days at temperatures of about $27^{\circ} \mathrm{C}$, with a germination rate of $67 \%$.

\section{Utilization of Gongronema latifolium}

Gongronema latifolium is an important plant that is utilized for 

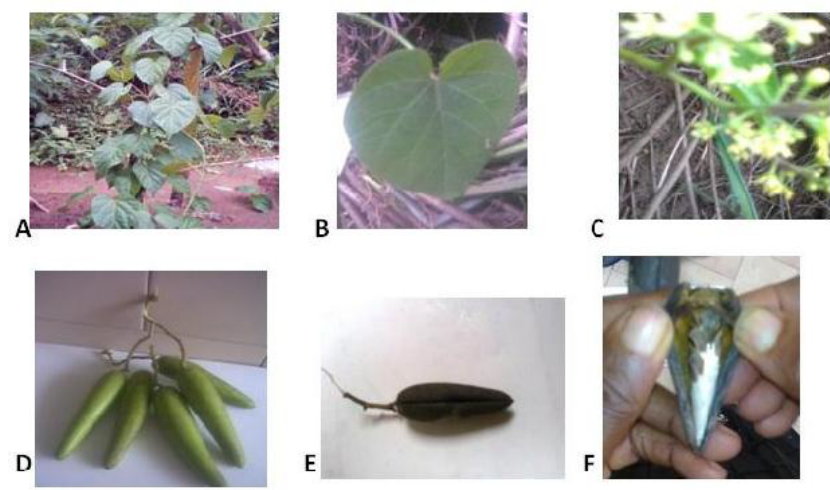

Figure 1: Legend to Plates A, B, C, D, E and F,

A: Leaves on G. latifolium plant.

B: A single leaf of $G$. latifolium.

C: The inflorescence.

D: A bunch of the fresh fruits.

E: A dry fruit showing the single seam.

F: Opened dry fruit showing seed arrangement with tuft of pappus.

\begin{tabular}{|c|c|c|c|c|c|c|c|}
\hline $\begin{array}{l}\text { Phytochemicals } \\
\text { (\%) }\end{array}$ & df & $\begin{array}{l}\text { Fruits } \\
(x \pm S . E)\end{array}$ & $\begin{array}{l}\text { Leaves } \\
(x \pm S . E)\end{array}$ & tcalculated & $5 \%$ & $1 \%$ & $0.1 \%$ \\
\hline Alkaloids & 2 & $50.0 \pm 0.58$ & $10.0 \pm 0.02$ & $70^{* * *}$ & 2.78 & 4.60 & 8.61 \\
\hline Tannins & 2 & $35.5 \pm 0.43$ & $30.0 \pm 0.01$ & $13.1^{\star * *}$ & 2.78 & 4.60 & 8.61 \\
\hline Saponins & 2 & $150.0 \pm 0.05$ & $38.0 \pm 0.01$ & $5600^{* * *}$ & 2.78 & 4.60 & 8.61 \\
\hline Flavonoids & 2 & $21.2 \pm 0.02$ & $23.4 \pm 0.01$ & $157.1^{* * *}$ & 2.78 & 4.60 & 8.61 \\
\hline Phenols & 2 & $10.4 \pm 0.01$ & $7.1 \pm 0.02$ & $194.1^{* * *}$ & 2.78 & 4.60 & 8.61 \\
\hline Phytic acid & 2 & $25.0 \pm 0.10$ & $20.0 \pm 0.01$ & $16.1^{* * *}$ & 2.78 & 4.60 & 8.61 \\
\hline Oxalate & 2 & ND & ND & - & - & - & - \\
\hline Hydrocyanic acid & 2 & $70.0 \pm 0.29$ & $48.5 \pm 0.01$ & $76.8^{* * \star}$ & 2.78 & 4.60 & 8.61 \\
\hline
\end{tabular}

Table 2: Phytochemicals analysis of the leaves and fruits of Gongronema latifolium.

its medicinal and culinary properties. In Nigeria, the species is utilized mostly by people from the South-Eastern region where it is popularly known as 'Utazi' by the Ibos and 'Utasi' by the Efiks and Ibibios. The parts used are the leaves/vines and the tender fruits.

Leaves: A few of the leaves are chopped and added to foods such as porridges, stews and pepper soups. Two very popular Ibo delicacies known as Nkwobi (Cow leg pepper soup) and Isi ewu (Goat head pepper soup) are prepared with G. latifolium leaves. According to findings from respondents, the leaves impart a sharp bitter taste and sweet aroma to food and it increases appetite and this has also been reported by Adelaja and Fasidi, FAO [9,17].

The crude extract from the leaves and vines are mixed with lime juice and drunk to expel worms and dispel stomach upsets and crams. The crude extract is mixed with extracts of bitter leaf (Vernonia amygdalina) and scent leaf (Ocimum gratissimum) and taken to treat malaria and typhoid fever [18].

The extract is taken alone to maintain healthy blood glucose level and to check excesses of diabetes and hypertension. Ugochukwu et al. and Ogundipe et al. $[19,20]$ have established the hypoglycemic, hypolipidemic and antioxidant properties of aqueous and ethanolic extracts of G. latifolium leaves. The extract is also used as enema, for treatment of malaria and stomach disorders.

Fruits: One or two young follicles are eaten daily with or without the seeds to treat stomach ache, check diabetes, treat malaria and tone the blood.

\section{Phytochemical differences in fruits and leaves of Gongronema latifolium}

The results showed that there is high significant difference, $(\mathrm{P}<0.001)$ in the quantity of phytochemicals (alkaloids, tannins, saponins, flavonoids, phytic acid and hydrocyanic acid) in the fruits and leaves. Oxalate was not detected in either the leaf or fruit samples. However, alkaloids, tannins, saponins, phenols, phytic acid and hydrocyanic acid have relatively higher percentage quantities in the fruits compared to the leaves while flavonoid content was however higher in the leaves than in the fruits (Table 2).

The presence of phytochemicals confers nutritional, industrial, therapeutic, as well as economic potentials on Gongronema latifolium. Saponins, flavonoids, tannins and alkaloids have chemo-preventive properties and the concept of chemo-prevention has assumed a global significance as a result of its acceptance in the management, prevention and treatment of a wide range of life threatening diseases such as cancer, diabetes and coronary diseases and in the maintenance of good health [21]. Alkaloids also have antipyretic effects [22]. Phenols are considered as antimicrobial (bacteriostatic and fungistatic) agents and play an active role in disease resistance and prevention [23]. Many reports suggest a positive correlation between total phenolic content and antioxidant activity [24]. A higher phenolic content recorded in the fruit of Gongronema latifolium as compared to the leaves indicate good antioxidant property. Alkaloids and phenols are more in the fruits than in the leaves of G. latifolium, this may be due also, to the need to preserve the seeds from microbial attack [25]. Flavonoids provide antioxidant and anti-inflammatory actions while saponins are used to recover homeostasis and are also anti-fungal $[26,27]$. The presence of saponins and tannins may be responsible for the bitter and astringent taste of the plant. The presence of saponins in G. latifolium also indicate that intake of the plant can clear fatty compounds from the body, lowering the blood cholesterol [28]. Tannins have traditionally been considered as anti-nutritional but it is now known that their beneficial or anti-nutritional properties depend on their dosage. Recent studies have demonstrated that low dosages are beneficial while high dosages especially in sensitive individuals may cause bowel irritation, kidney and stomach irritation, liver damage and gastro-intestinal pain. Excess intake of tannins is therefore not recommended, and G. latifolium leaves or fruits should be taken in small amounts. Tannins are effective in protecting the kidney and deactivating the effect of poliovirus, herpes simplex virus and various enteric viruses. They also show antibacterial and anti-parasitic effects and are used in the treatment of hereditary hemochromatosis [29]. Phytic acid has also been considered asanti-nutritional substance but however, recent research has shown its many health benefits such as antioxidant, anticancer, hypocholesterol and hypolipidemic effects. Phytic acid releases inositol that might help reduce depression and inflammation [27]. Kushi et al. [6], reported that hydrocyanic acid is a successful remedy for whooping cough, employed to alloy cerebral disorders, relieve itching, curbing various kinds of nervous disorders such as vomiting, gastralgia, and pain caused by indigestion, irritative dyspepsia, and enteralgia. It is also an expellant for worm infection.

\section{Conclusion}

This work has X-rayed the biology and utilization of Gongronema latifolium and has confirmed the observation by locals that the fruits of G. latifolium are even more potent than its leaves due to the higher concentration of most of its phytochemical constituents. It is advisable therefore that lesser quantities of fruits should be consumed to avoid 
Citation: Osuagwu AN, Ekpo IA, Okpako EC, Otu P, Ottoho E (2013) The Biology, Utilization and Phytochemical Composition of the fruits and leaves of Gongronema latifolium Benth. Agrotechnol 2: 115. doi:10.4172/2168-9881.1000115

Page 4 of 4

the effect of over dosage. The results from this work suggest that Gongronema latifolium may find its use in food/feed formulation/ supplementation as well as nutriceutical/medicinal and industrial uses.

\section{Acknowledgement}

This research is an aspect of the research project in the University Of Calabar funded by STEP-B in conjunction with the World Bank. We acknowledge and thank the donors.

\section{References}

1. Akinsanmi FA, Akindele SO (2002) Timber yield assessment in the natural forest area of Oluwa forest reserve, Nigeria. Nigerian Journal of Forestry 32: 16-22.

2. Gillespie TW (2004) Prospects for quantifying structure, floristic composition and species richness of tropical forest. International Journal of Remote Science 25: 707-715.

3. Abraham Z (1981) Glimpse of Indian Ethnobotany. Oxford \& Publishing Co., New Delhi, India. 308-320.

4. Chhetri HP, Vogol NS, Sherchan J, Anupa KC, Mansoor S, et al. (2008) Phytochemical and antimicrobial evaluations of some medicinal plants of Nepal.Kathmandu University Journal of Science, Engineering and Technology. 1: 49-54.

5. Liu RH (2004) Potential synergy of phytochemicals in cancer prevention: mechanism of action. J Nutr 134: 3479S-3485S.

6. Kushi LH, Byers T, Doyle C, Bandera EV, McCullough M, et al. (2006) American Cancer Society Guidelines on Nutrition and Physical Activity for cancer prevention: reducing the risk of cancer with healthy food choices and physical activity. CA Cancer J Clin 56: 254-281.

7. Setchell KD, Cassidy A (2003) Dietry isoflavones: Biological effects and relevance to human health. Journal of Nutrition 129: 758-767.

8. Wang YH, Chao PD, Hsiu SL, Wen KC, Hou YC (2004) Lethal quercetin-digoxin interaction in pigs. Life Sci 74: 1191-1197.

9. Adelaja BA, Fasidi IO (2009) Survey and collection of indigenous spice germplasm for conservation and genetic improvement of Nigeria. Bioversity International 153: 67-71.

10. Sofowora A (1993) Screening of plants for bioactive agents in medicinal plants and traditional medicine in Africa. (2nd ed) Spectrum Books Ltd, Sunshine House, Ibadan. 81-93, 135-156.

11. Edeoga HO, Okwu DE, Mbaebie BO (2005) Phytochemical constituents of some Nigerian medical plants. African Journal of Biotechnology 4: 685-688.

12. Trease GE, Evans WC( 1978) A textbook of Pharmacognosy. (11th Edition). Bailliese, Tindall, London. 397-53.
13. Andrews WH (1994) Update on validation of microbiological methods by AOAC International. J AOAC Int 77: 925-931.

14. Tsiang Ving, Li Ping-tao (1977) Asclepiadaceae. FI. Republic Popularis Sin 63 249-575.

15. Burkhill HM (1985) The useful plants of West Tropical Africa. (2 ${ }^{\text {nd }}$ Ed) Kew, Royal Botanical Gardens, Great Britain. 960

16. Global Biodiversity Information Facility (GBIF).

17. FAO/Food and Agriculture Organization of the United Nations (1983) Food and fruit bearing forest species: Examples from Eastern Africa. FAO Forestry paper 44: 172.

18. Atangwho IJ,Ebong PE, Eyong EU, Williams IO, Eteng MU, et al. (2009) Comparative Chemical composition of leaves of some antidiabetic medicinal plants: Azadirachta indica, Vernonia amygdalina and Gongronema latifolium. African Journal of Biotechnology 8: 4685-4689.

19. Ugochukwu NH, Babady NE, Cobourne M, Gasset SR (2003) The effect of Gongronema latifolium extracts on serum lipid profile and oxidative stress in hepatocytes of diabetic rats. J Biosci 28: 1-5.

20. Ogundipe OO, Moody JO, Akinyemi TO, Raman A (2003) Hypoglycemic potentials of methanolic extracts of selected plant foods in alloxanized mice. Plant Foods and Human Nutrition 58: 1-7.

21. Greenwald P, Kelloff GJ (1996) The role of chemoprevention in cancer control. IARC Sci Publ: 13-22.

22. Okwu DE (2005) Phytochemicals, vitamins and mineral content of two Nigeria medicinal plants. International Journal of Molecular Medicine and Advance Sciences. 1: 375-381.

23. Matern U, Kneusel RE (1980) Phenolic compounds in plant disease resistance. Phytoparasitica 16: 153-170.

24. Salah N, Miller NJ, Paganga G, Tijburg L, Bolwell GP, et al. (1995) Polyphenolic flavanols as scavengers of aqueous phase radicals and as chain-breaking antioxidants. Arch Biochem Biophys 322: 339-346.

25. Okwu DE, Emenike IN (2006) Evaluation of the phytonutrients and vitamin content of citrus fruits. International Journal of Molecular Medicine and Advance Sciences 2: 1-6.

26. Galeotti F, Barlie E, Curir R, Doki M, Lanzotti V (2008) Flavonoids from Carnation (Dianthus caryophyllus) and their anti fungal activity. Phytochemistry letters 1-44.

27. Russel AD , Chopra I (1990) Understanding anti bacterial action and resistance. Ellis Horwood Limited, New York, USA. 131

28. Vaghasiya Y, Dave R, Chanda S (2011) Phytochemical analysis of some medicinal plants from Western region of India. Research Journal of Medicinal Plant 5: 567-576.

29. Burkhill HM (1977) The useful plants of West Tropical Africa. (3 $3^{\text {rd }}$ ed). Royal Botanic Gardens Kew, Great Britain. 55-56. 